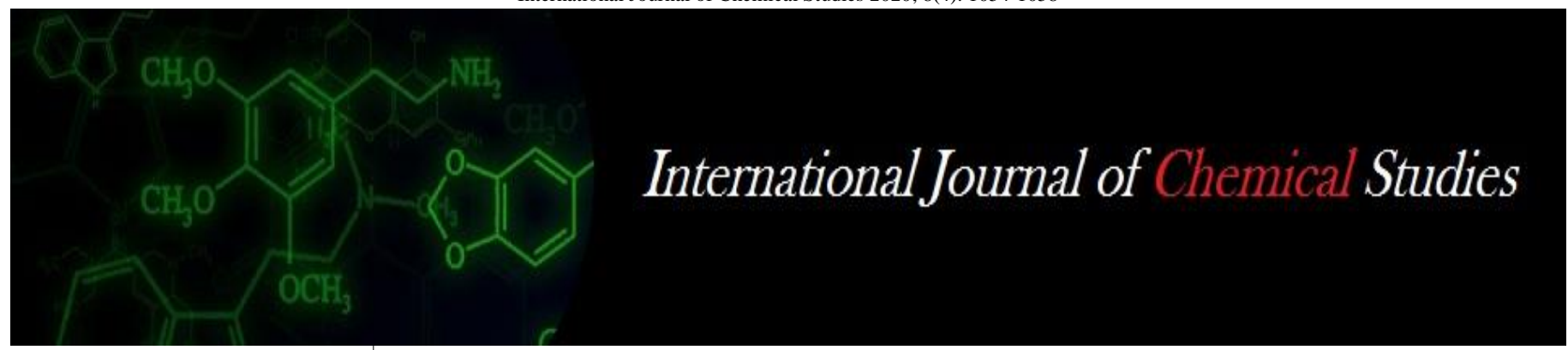

P-ISSN: 2349-8528

E-ISSN: 2321-4902

www.chemijournal.com

IJCS 2020; 8(4): 1054-1058

(C) 2020 IJCS

Received: 10-05-2020

Accepted: 14-06-2020

M Naveen Kumar Reddy

Department of Livestock

Products Technology, College of

Veterinary Science, PVNR

Telangana Veterinary

University, Rajendranagar,

Hyderabad, Telangana, India

\section{Shashi Kumar}

Department of Livestock

Products Technology, College of

Veterinary Science, PVNR

Telangana Veterinary

University, Rajendranagar,

Hyderabad, Telangana, India

GV Bhaskar Reddy

Department of Livestock

Products Technology, College of

Veterinary Science, PVNR

Telangana Veterinary

University, Rajendranagar,

Hyderabad, Telangana, India

\section{N Krishnaiah}

Department of Livestock

Products Technology, College of

Veterinary Science, PVNR

Telangana Veterinary

University, Rajendranagar,

Hyderabad, Telangana, India

\section{N Anitha Reddy}

Department of Livestock

Products Technology, College of

Veterinary Science, PVNR

Telangana Veterinary

University, Rajendranagar,

Hyderabad, Telangana, India

\section{Maheswara Reddy}

Department of Livestock

Products Technology, College of

Veterinary Science, PVNR

Telangana Veterinary

University, Rajendranagar,

Hyderabad, Telangana, India

Corresponding Author:

M Naveen Kumar Reddy

Department of Livestock

Products Technology, College of

Veterinary Science, PVNR

Telangana Veterinary

University, Rajendranagar,

Hyderabad, Telangana, India

\section{Storage stability of vacuum packaged turkey meat sausages incorporated with carrot and radish paste during refrigerated storage}

\author{
M Naveen Kumar Reddy, M Shashi Kumar, GV Bhaskar Reddy, N \\ Krishnaiah, N Anitha Reddy and D Maheswara Reddy
}

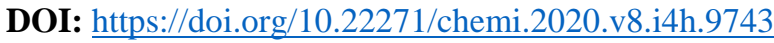

\begin{abstract}
The present study was intended to evaluate the shelf life of vacuum packed turkey meat sausages incorporated with raw carrot paste (RCP) and raw radish paste (RRP) each at $10 \%$ level under refrigeration $\left(4 \pm 1{ }^{\circ} \mathrm{C}\right)$ for a period of 25 days. The sausages were evaluated for physico-chemical, microbiological and organoleptic quality at an interval of 5 days during refrigeration storage. The quality parameters were significantly $(P<0.05)$ affected due to the incorporation of raw carrot paste $(\mathrm{RCP})$ and raw radish paste (RRP) and also due to refrigeration storage. The results revealed that there was a significant $(P<0.05)$ increase in the $\mathrm{pH}$, TBARS value and Tyrosine value as storage progressed from 0 25 days. However, the values were well below the threshold level of spoilage. Standard plate counts increased significantly $(P<0.05)$ as storage period progressed from $0-25$ days. Psychrophilic counts were not detected in the control and treated sausages at $0^{\text {th }}$ day, afterwards the psychrophilic counts increased significantly $(P<0.05)$ as storage period progressed from 5-25 days. Yeast and mould counts were not detected in any of the products throughout the entire storage period. Sensory evaluation revealed a decrease in the sensory scores with the advancement of storage during entire storage period. Based on the results, it can be concluded addition of raw carrot paste (RCP) and raw radish paste (RRP) each at $10 \%$ level would not only extends the shelf life by protecting the product longer against oxidative rancidity but also had higher acceptability than control and their use in meat products can enhance the shelf life up to 25 days under refrigerated storage without undesirable changes.
\end{abstract}

Keywords: Turkey meat sausages, carrot paste, radish paste, physico-chemical quality, vacuum packaging

\section{Introduction}

Turkey meat has wide acceptability among Indian consumers. Turkey meat is preferred all over the country for its unique taste and flavour and is sold at premium rate without any religious taboos. Generally, meat has a special place in the diet because of its appealing flavour, texture and its high nutritional value. In spite of modern improved slaughter and food production techniques, lipid oxidation and microbial growth are the primary factors of spoilage of meat during refrigeration storage. Now a day's consumers are demanding the meat products with natural antioxidants due to drawbacks of synthetic antioxidants. Some of the vegetables have antioxidant and antimicrobial properties. Carrot can be used as a source of dietary fibre in meat products. Carrots are perhaps best known for their rich content of antioxidant like beta carotene. Carotenoids represent a large group of phytochemicals that may contribute to health and disease prevention (Otles and Cagindi 2009) ${ }^{[1]}$. Radish have higher amount of phenolic compounds and higher antioxidant capacity (Mercier et al. 2015) [2]. Since, very limited research work have been carried out on suitability of carrot and radish vegetables as natural extenders, anti-oxidants and antimicrobials on the comminuted meat products, the present work is therefore planned to find out the effect of incorporation of carrot, radish on the quality and shelf life of vacuum packed Turkey meat sausages stored at refrigeration temperature $\left(4 \pm 1^{\circ} \mathrm{C}\right)$. 


\section{Materials and methods}

Source of raw material

Tom turkey birds (Broad Breasted White) of 25-30 weeks of age were procured from the Poultry Research Station, Rajendranagar, Hyderabad slaughtered and dressed adopting standard procedure at the Department of Livestock Products Technology, College of Veterinary Science, Rajendranagar, Hyderabad. Carrot and Radish were procured from local vegetable market, washed with tap water for cleaning and removal of extraneous dirt. The cleaned vegetables were peeled manually with peeler, cut into slices and were made into a paste by using a home mixer / grinder and analytical grade chemicals and food grade additives were procured from standard companies.

\section{Preparation of turkey meat sausages}

The turkey meat was minced using meat mincer (Model: Sirman TC 32 Colorado, Italy) using $8 \mathrm{~mm}$ plate followed by $4 \mathrm{~mm}$ plate. Sausages were prepared using ingredients as per the recipe presented in Table-1 viz., Control, Carrot and Radish incorporated each at $10 \%$ level replacing lean meat. Emulsion was prepared in Bowl Chopper (Model: MADO Garrant MTK 661, Germany). The fresh boneless turkey meat cut into small chunks and minced in a meat mincer (Sirman,TC $12 \mathrm{E}$, Italy) through $4 \mathrm{~mm}$ plate. The emulsion was prepared by chopping the minced meat along with other non-meat ingredients in a bowl chopper (Scharfen, Model No: TC 11, Germany). The minced chicken meat was mixed with salt@1.5\%, STPP@ 0.4\%, sodium nitrate@150 ppm, sodium ascorbate@500 ppm, sugar@1\% and ice flakes@ $8 \%$ and chopped for one min followed by addition of oil @ $6 \%$ and again chopped for one min and added corn flour @ $3 \%$, spice mix @1.6, condiment mix @ 3\% (onion and garlic: 3:1), carrot paste @10\% and radish paste @ $10 \%$ respectively in T1 and T2 sausages and finally chopped for 3 min. The temperature of the emulsion was maintained between 12 to $15^{\circ} \mathrm{C}$. The emulsions of control, T1 and T2 was separately stuffed into synthetic cellulose casings (SCC21) using horizontal sausage stuffer and cooked at $80^{\circ} \mathrm{C} / 20 \mathrm{~min}$ in moist heat. After cooking the sausages were cooled to room temperature and chilled under refrigeration for few minutes followed by packing in HDPE pouches under vacuum packaging and stored at refrigerated $\left(4 \pm 1^{\circ} \mathrm{C}\right)$ storage and evaluated every 5 days interval up to 25 days.

\section{Analytical parameters}

For shelf-life studies, $\mathrm{pH}$ was determined by following the procedure of Trout et al. (1992) ${ }^{[3]}$. Thiobarbituric Acid Reacting Substances (TBARS) value was estimated by the procedure of Tarladgis et al. (1960) ${ }^{[4]}$. Tyrosine value was estimated adopting the procedure of Strange et al. (1977) ${ }^{[5]}$. The Standard plate counts (SPC), Psychrophilic counts (PPC) and Yeast and mould counts (YMC) per gram of Turkey meat sausages stored at refrigerated temperature were estimated as per the procedure recommended by Chestnut et al. (1977) ${ }^{[6]}$. The sensory panel consisted of six semi-trained faculty members of the college which evaluated various sensory attributes like colour, flavour, juiciness, tenderness and overall acceptability by using an 8point hedonic scale (Keeton $1983)^{[7]}$ where, $8=$ extremely good and $1=$ extremely poor. The experiment was repeated thrice and the samples were analyzed in duplicate. The data thus obtained was subjected to statistical analysis using SPSS MAC, version 20.0, SPSS Chicago (USA).

\section{Results and Discussion Physico-chemical properties}

Effect of incorporation of RCP and RRP on pH, TBARS and Tyrosine value (TV) of vacuum packaged turkey meat sausages during refrigerated $\left(4 \pm 1^{\circ} \mathrm{C}\right)$ storage are presented in Table 1.

\section{pH}

The $\mathrm{pH}$ of sausages decreased significantly $(P<0.05)$ throughout the storage period. The decrease in $\mathrm{pH}$ was however non significant upto $5^{\text {th }}$ day of storage, but significantly $(P<0.05)$ decreased subsequently. The decrease in $\mathrm{pH}$ during storage might be due to increase in lactic acid content due to the action of lactic acid bacteria degrading carbohydrates. Control group recorded highest $\mathrm{pH}$ during storage followed by carrot and radish incorporated turkey meat sausages. Incze (1992) ${ }^{[8]}$ reported that decrease in the $\mathrm{pH}$ values might be due to significant increase in microbial count during storage period producing lactic acid by breakdown of carbohydrates. Santos et al. (2005) ${ }^{[9]}$ reported that vacuum packed sausages stored under refrigeration temperature have shown decrease in $\mathrm{pH}$.

\section{Tyrosine value}

Tyrosine values increased significantly $(P<0.05)$ during entire refrigerated storage irrespective of treatment and control. Increase in tyrosine values during storage may be attributed to breakdown of proteins. Similar increase in tyrosine values during refrigerated storage were reported by Ahamed et al. (2007) ${ }^{[10]}$ in enrobed beef meat cutlets and Biswas et al. (2011) ${ }^{[11]}$ in duck patties.

\section{Thiobarbituric Acid Reactive Substances (TBARS) value}

During storage, TBARS value of control was observed to be significantly $(P<0.05)$ higher as compared to that of carrot and radish incorporated turkey meat sausages. The TBARS values of three products increased significantly $(P<0.05)$ throughout storage period of 25 days. However the values recorded were lower than the threshold value of TBARS. Among the three types of turkey meat sausages, lower TBRAS value was observed in radish incorporated turkey meat sausages as compare to control and carrot incorporated turkey meat sausages which might be due to antioxidant activity of carotenoids present in radish. Similar observations were recorded by Bhosale (2009) ${ }^{[12]}$ in chicken nuggets and Yadav et al. (2018) ${ }^{[13]}$ in chicken sausages.

\section{Microbiological quality \\ Standard plate count}

It was observed that the total plate count of three types of turkey meat sausages differ significantly. Control had higher total plate count than carrot and radish incorporated turkey meat sausages. Radish incorporated turkey meat sausages had lower TPC which might be due to their antimicrobial effect. Antimicrobial effect of radish chip extract in pork sausages was reported by Sugita et al. (1993) ${ }^{[14]}$. However, the microbial counts increased significantly $(P<0.05)$ with the progress of refrigerated storage up to 25 days. Similar trend was observed by Bhaskar Reddy et al. (2013) ${ }^{[15]}$ in restructured mutton slices, Bhaskar Reddy et al. (2017) ${ }^{[16]}$ in functional chevon sausages and Yadav et al. (2018) in chicken sausages. At the end of storage, the TPC was below the incipient spoilage level of $6.70 \mathrm{log} \mathrm{cfu} / \mathrm{g}$. 


\section{Psychrophilic count}

Psychrophills were not detected on 0 day but the PC increased significantly $(P<0.05)$ throughout the storage period as storage progressed which might be due to growth preference of psychrophilic organisms during storage at refrigeration temperature. Lower psychrophilic count were recorded for radish incorporated and carrot incorporated turkey meat sausages as compared to control, which might be due lower level of nutrition provided by treated products to microorganisms, their antimicrobial activity and also due to lower $\mathrm{pH}$ of added

Table 1: Effect of incorporation of Carrot and Radish paste on physico-chemical and microbial quality of vacuum packed Turkey meat sausages during refrigeration storage $\left(4 \pm 1^{\circ} \mathrm{C}\right)(\mathrm{Mean} \pm \mathrm{SE})$.

\begin{tabular}{|c|c|c|c|c|c|c|}
\hline \multirow{2}{*}{ Treatments } & \multicolumn{6}{|c|}{ Storage days } \\
\hline & $\mathbf{0}$ & 5 & 10 & 15 & 20 & 25 \\
\hline \multicolumn{7}{|c|}{ pH } \\
\hline $\mathrm{C}$ & $6.28 \pm 0.02^{\mathrm{aA}}$ & $6.21 \pm 0.01^{\mathrm{aAB}}$ & $6.17 \pm 0.03^{\mathrm{aB}}$ & $6.07 \pm 0.11^{\mathrm{aC}}$ & $6.02 \pm 0.08^{\mathrm{aCD}}$ & $5.94 \pm 0.03^{\mathrm{aD}}$ \\
\hline T1 & $6.25 \pm 0.04^{\mathrm{aA}}$ & $6.23 \pm 0.05^{\mathrm{aA}}$ & $6.11 \pm 0.06^{\mathrm{bB}}$ & $6.04 \pm 0.07^{\mathrm{bC}}$ & $5.98 \pm 0.04^{\mathrm{bCD}}$ & $5.89 \pm 0.05^{\mathrm{bD}}$ \\
\hline \multirow[t]{2}{*}{$\mathrm{T} 2$} & $6.23 \pm 0.06^{\mathrm{aA}}$ & $6.21 \pm 0.02^{\mathrm{aA}}$ & $6.09 \pm 0.13^{\mathrm{bB}}$ & $6.02 \pm 0.05^{\mathrm{bBC}}$ & $5.94 \pm 0.06^{\mathrm{cC}}$ & $5.85 \pm 0.10^{\mathrm{cD}}$ \\
\hline & \multicolumn{6}{|c|}{ Tyrosine Value (mg/100g) } \\
\hline $\mathrm{C}$ & $3.25 \pm 0.17^{\mathrm{aF}}$ & $4.16 \pm 0.20^{\mathrm{aE}}$ & $6.61 \pm 0.11^{\mathrm{aD}}$ & $8.76 \pm 0.23^{\mathrm{aC}}$ & $10.18 \pm 0.30^{\mathrm{aB}}$ & $13.81 \pm 0.25^{\mathrm{aA}}$ \\
\hline $\mathrm{T} 1$ & $2.77 \pm 0.16^{\mathrm{bF}}$ & $4.52 \pm 0.23^{\mathrm{abE}}$ & $6.56 \pm 0.13^{\mathrm{aD}}$ & $7.43 \pm 0.29^{\mathrm{bC}}$ & $9.56 \pm 0.29^{\mathrm{abB}}$ & $12.52 \pm 0.35^{\mathrm{bA}}$ \\
\hline \multirow[t]{2}{*}{$\mathrm{T} 2$} & $2.39 \pm 0.22^{\mathrm{bF}}$ & $3.05 \pm 0.42^{\mathrm{cE}}$ & $5.18 \pm 0.25^{\mathrm{bD}}$ & $6.62 \pm 0.31^{\mathrm{cC}}$ & $8.97 \pm 0.27^{\mathrm{bB}}$ & $11.93 \pm 0.29^{\mathrm{bA}}$ \\
\hline & \multicolumn{6}{|c|}{ TBARS Value (mg malonaldehyde/kg) } \\
\hline $\mathrm{C}$ & $0.31 \pm 0.03^{\mathrm{aD}}$ & $0.37 \pm 0.03^{\mathrm{aCD}}$ & $0.49 \pm 0.05^{\mathrm{aBC}}$ & $0.61 \pm 0.04^{\mathrm{aAB}}$ & $0.68 \pm 0.02^{\mathrm{aA}}$ & $0.74 \pm 0.06^{\mathrm{aA}}$ \\
\hline $\mathrm{T} 1$ & $0.26 \pm 0.02^{\mathrm{bD}}$ & $0.29 \pm 0.01^{\mathrm{bD}}$ & $0.36 \pm 0.03^{\mathrm{bCD}}$ & $0.42 \pm 0.03^{\mathrm{bBC}}$ & $0.50 \pm 0.04^{\mathrm{bAB}}$ & $0.56 \pm 0.04^{\mathrm{bA}}$ \\
\hline \multirow[t]{2}{*}{$\mathrm{T} 2$} & $0.22 \pm 0.04^{\mathrm{bD}}$ & $0.25 \pm 0.02^{\mathrm{bCD}}$ & $0.28 \pm 0.02^{\mathrm{cBCD}}$ & $0.33 \pm 0.01^{\mathrm{cBC}}$ & $0.38 \pm 0.03^{\mathrm{cAB}}$ & $0.45 \pm 0.02^{\mathrm{cA}}$ \\
\hline & \multicolumn{6}{|c|}{ Standard Plate Count $(\log$ CFU/g) } \\
\hline $\mathrm{C}$ & $2.82 \pm 0.17^{\mathrm{aC}}$ & $3.16 \pm 0.20^{\mathrm{aC}}$ & $3.49 \pm 0.11^{\mathrm{aBC}}$ & $3.96 \pm 0.23^{\mathrm{aAB}}$ & $4.18 \pm 0.30^{\mathrm{aAB}}$ & $4.34 \pm 0.25^{\mathrm{aA}}$ \\
\hline $\mathrm{T} 1$ & $2.54 \pm 0.16^{\mathrm{bC}}$ & $2.79 \pm 0.23^{\mathrm{bC}}$ & $3.18 \pm 0.13^{\mathrm{bBC}}$ & $3.65 \pm 0.29^{\mathrm{bAB}}$ & $3.89 \pm 0.29^{\mathrm{aAB}}$ & $4.17 \pm 0.35^{\mathrm{abA}}$ \\
\hline \multirow[t]{2}{*}{$\mathrm{T} 2$} & $2.13 \pm 0.22^{\mathrm{cC}}$ & $2.27 \pm 0.42^{\mathrm{cC}}$ & $2.980 .25^{\mathrm{bB}}$ & $3.19 \pm 0.31^{\mathrm{cAB}}$ & $3.37 \pm 0.27^{\mathrm{bAB}}$ & $3.59 \pm 0.29^{\mathrm{bA}}$ \\
\hline & \multicolumn{6}{|c|}{ Psychrophilic Count (log CFU/g) } \\
\hline $\mathrm{C}$ & ND & $2.26 \pm 0.21^{\mathrm{aC}}$ & $2.81 \pm 0.17^{\mathrm{aC}}$ & $3.46 \pm 0.11^{\mathrm{aB}}$ & $3.96 \pm 0.13^{\mathrm{aAB}}$ & $4.18 \pm 0.31^{\mathrm{aA}}$ \\
\hline $\mathrm{T} 1$ & ND & $1.98 \pm 0.18^{\mathrm{aC}}$ & $2.34 \pm 0.28^{\mathrm{bC}}$ & $2.97 \pm 0.20^{\mathrm{bB}}$ & $3.38 \pm 0.29^{\mathrm{bAB}}$ & $3.71 \pm 0.18^{\mathrm{bA}}$ \\
\hline $\mathrm{T} 2$ & ND & $1.33 \pm 0.17^{\mathrm{bCD}}$ & $1.67 \pm 0.09^{\mathrm{cCD}}$ & $1.95 \pm 0.16^{\mathrm{cC}}$ & $2.54 \pm 0.21^{\mathrm{cB}}$ & $3.12 \pm 0.16^{\mathrm{cA}}$ \\
\hline
\end{tabular}

Means with different superscripts in the same row (upper case letters) and column (lower case letters) differed significantly $(P<0.05)$.

C-Control T1-Carrot incorporated sausages T2- Radish incorporated sausages vegetables. Similar observations were reported by Yadav and Sharma (2004) ${ }^{[17]}$ in low fat chevon rolls and Yadav et al. (2018) ${ }^{[13]}$ in chicken sausages.

\section{Yeast and mould count}

Yeast and mould counts were not detected on the day of preparation as well as at any point of storage periods which might be due to good hygienic conditions at the time of processing as well as post processing handling. Similar findings were reported by Biswas et al. (2004) ${ }^{[18]}$ in precooked pork patties and Yadav et al. (2018) ${ }^{[13]}$ in chicken sausages.

\section{Sensory evaluation}

The sensory scores for appearance of turkey meat sausages decreased during storage which was not significant up to $15^{\text {th }}$ day of storage. And thereafter it declined significantly $(P<$ $0.05)$ till the end of storage this might be due to pigment breakdown and lipid oxidation resulting in non-enzymatic browning (Chenman et al. 1995) ${ }^{[19]}$. The appearance scores of carrot incorporated turkey meat sausages was significantly $(P<0.05)$ higher than the radish incorporated sausages and control.

The flavour score was stable upto $10^{\text {th }}$ day thereafter declined significantly $(P<0.05)$ with increase in storage period in both control and treatments which might be due to microbial growth and lipid oxidation. However radish incorporated turkey meat sausages had significantly higher $(P<0.05)$ flavor score than control and carrot incorporated turkey meat sausages which might be attributed to raw radish. Similar reduction in flavour scores during storage were reported by Bhosale (2009) ${ }^{[12]}$ in chicken nuggets, Bhaskar Reddy et al.
(2017) ${ }^{[16]}$ in functional chevon sausages and Yadav et al. (2018) ${ }^{[13]}$ in chicken sausages.

The sensory scores for texture declined non significantly up to $10^{\text {th }}$ day of storage, thereafter the scores reduced significantly $(P<0.05)$ with the progress of storage which might be attributed to loss of moisture leading to hardening and also due to breakdown of fat and protein. Irrespective of storage period, radish incorporated turkey meat sausages exhibited optimum scores. The findings of the present study corroborated with the results of Ahmed et al. (2007) ${ }^{[10],}$ Bhaskar Reddy et al. (2017) ${ }^{[16]}$ in functional chevon sausages and Yadav et al. (2018) ${ }^{[13]}$ in chicken sausages.

The juiciness scores of turkey meat sausages decreased significantly $(P<0.05)$ during the refrigerated storage which might be due to dehydration and moisture reduction of the product with advancement of refrigerated storage. Irrespective of storage, carrot incorporated turkey meat sausages and radish incorporated turkey meat sausages recorded significantly $(P<0.05)$ higher scores over control but did not differed significantly among them. The present findings were in agreement with Ahmed et al. (2007) ${ }^{[10]}$ in enrobed buffalo meat cutlets, Bhaskar Reddy et al. (2017) ${ }^{[16]}$ in functional chevon sausages and Yadav et al. (2018) ${ }^{[13]}$ in chicken sausages. It was observed that overall acceptability scores were no significant upto $15^{\text {th }}$ day of storage, but afterwards decreased significantly $(P<0.05)$ during entire storage period. Moreover, the scores for overall palatability were significantly higher for radish incorporated turkey meat sausages indicating that the overall quality was much better than that of control as well as carrot incorporated turkey meat sausages. Similar observation of decrease in overall acceptability was also reported by Bhaskar Reddy et al. $(2017)^{[16]}$ in functional chevon sausages. 
Table 2: Effect of incorporation of Carrot and Radish on the Sensory scores of Vacuum packed Turkey meat sausages stored under refrigeration $\left(4 \pm 1^{\circ} \mathrm{C}\right)($ Mean $\pm \mathrm{SE})$.

\begin{tabular}{|c|c|c|c|c|c|c|}
\hline \multirow{2}{*}{ Treatments } & \multicolumn{6}{|c|}{ Storage days } \\
\hline & $\mathbf{0}$ & 5 & 10 & 15 & 20 & 25 \\
\hline \multicolumn{7}{|c|}{ Appearance } \\
\hline $\mathrm{C}$ & $7.30 \pm 0.01^{\mathrm{cA}}$ & $7.28 \pm 0.05^{\mathrm{cA}}$ & $7.18 \pm 0.13^{\mathrm{cA}}$ & $7.11 \pm 0.18^{\mathrm{cA}}$ & $6.86 \pm 0.25^{\mathrm{cB}}$ & $6.37 \pm 0.28^{\mathrm{cC}}$ \\
\hline $\mathrm{T} 1$ & $7.46 \pm 0.03^{\mathrm{aA}}$ & $7.40 \pm 0.15^{\mathrm{aA}}$ & $7.31 \pm 0.07^{\mathrm{aA}}$ & $7.23 \pm 0.11^{\mathrm{aA}}$ & $7.04 \pm 0.08^{\mathrm{aB}}$ & $6.66 \pm 0.16^{\mathrm{aC}}$ \\
\hline \multirow[t]{2}{*}{$\mathrm{T} 2$} & $7.33 \pm 0.03^{\mathrm{bA}}$ & $7.31 \pm 0.12^{\mathrm{bA}}$ & $7.22 \pm 0.02^{\mathrm{bA}}$ & $7.15 \pm 0.06^{\mathrm{bA}}$ & $6.92 \pm 0.15^{\mathrm{bB}}$ & $6.54 \pm 0.17^{\mathrm{bC}}$ \\
\hline & \multicolumn{6}{|c|}{ Flavour } \\
\hline $\mathrm{C}$ & $7.43 \pm 0.04^{\mathrm{aA}}$ & $7.34 \pm 0.07^{\mathrm{aA}}$ & $7.24 \pm 0.15^{\mathrm{aA}}$ & $6.87 \pm 0.18^{\mathrm{cB}}$ & $6.62 \pm 0.03^{\mathrm{cC}}$ & $6.37 \pm 0.04^{\mathrm{cD}}$ \\
\hline $\mathrm{T} 1$ & $7.27 \pm 0.04^{\mathrm{bA}}$ & $7.21 \pm 0.12^{\mathrm{bA}}$ & $7.10 \pm 0.02^{\mathrm{bA}}$ & $6.94 \pm 0.07^{\mathrm{aB}}$ & $6.78 \pm 0.06^{\mathrm{aC}}$ & $6.63 \pm 0.02^{\mathrm{aD}}$ \\
\hline \multirow[t]{2}{*}{$\mathrm{T} 2$} & $7.32 \pm 0.05^{\mathrm{cA}}$ & $7.28 \pm 0.06^{\mathrm{cA}}$ & $7.18 \pm 0.16^{\mathrm{cA}}$ & $7.02 \pm 0.13^{\mathrm{bB}}$ & $6.92 \pm 0.08^{\mathrm{bC}}$ & $6.72 \pm 0.12^{\mathrm{bD}}$ \\
\hline & \multicolumn{6}{|c|}{ Texture } \\
\hline $\mathrm{C}$ & $7.06 \pm 0.07^{\mathrm{bA}}$ & $6.92 \pm 0.02^{\mathrm{bA}}$ & $6.82 \pm 0.11^{\mathrm{bA}}$ & $6.64 \pm 0.02^{\mathrm{bB}}$ & $6.45 \pm 0.06^{\mathrm{bB}}$ & $6.01 \pm 0.04^{\mathrm{bC}}$ \\
\hline $\mathrm{T} 1$ & $7.34 \pm 0.02^{\mathrm{aA}}$ & $7.19 \pm 0.04^{\mathrm{aA}}$ & $7.0 \pm 0.05^{\mathrm{aA}}$ & $6.81 \pm 0.04^{\mathrm{aB}}$ & $6.60 \pm 0.01^{\mathrm{aB}}$ & $6.37 \pm 0.12^{\mathrm{aB}}$ \\
\hline \multirow[t]{2}{*}{$\mathrm{T} 2$} & $7.35 \pm 0.02^{\mathrm{aA}}$ & $7.22 \pm 0.06^{\mathrm{aA}}$ & $7.06 \pm 0.03^{\mathrm{aA}}$ & $6.84 \pm 0.05^{\mathrm{aB}}$ & $6.62 \pm 0.03^{\mathrm{aB}}$ & $6.41 \pm 0.16^{\mathrm{aB}}$ \\
\hline & \multicolumn{6}{|c|}{ Juiciness } \\
\hline $\mathrm{C}$ & $6.94 \pm 0.05^{\mathrm{bA}}$ & $6.82 \pm 0.02^{\mathrm{bA}}$ & $6.72 \pm 0.14^{\mathrm{bA}}$ & $6.60 \pm 0.06^{\mathrm{bA}}$ & $6.32 \pm 0.01^{\mathrm{bB}}$ & $5.98 \pm 0.04^{\mathrm{bC}}$ \\
\hline $\mathrm{T} 1$ & $7.12 \pm 0.06^{\mathrm{aA}}$ & $7.04 \pm 0.08^{\mathrm{aA}}$ & $6.92 \pm 0.04^{\mathrm{aA}}$ & $6.84 \pm 0.03^{\mathrm{aA}}$ & $6.58 \pm 0.02^{\mathrm{aB}}$ & $6.38 \pm 0.17^{\mathrm{aB}}$ \\
\hline \multirow[t]{2}{*}{$\mathrm{T} 2$} & $7.23 \pm 0.07^{\mathrm{aA}}$ & $7.14 \pm 0.12^{\mathrm{aA}}$ & $6.98 \pm 0.05^{\mathrm{aA}}$ & $6.86 \pm 0.07^{\mathrm{aA}}$ & $6.61 \pm 0.13^{\mathrm{aB}}$ & $6.42 \pm 0.11^{\mathrm{aB}}$ \\
\hline & \multicolumn{6}{|c|}{ Overall Acceptability } \\
\hline $\mathrm{C}$ & $7.23 \pm 0.03^{\mathrm{cA}}$ & $7.12 \pm 0.11^{\mathrm{cA}}$ & $6.94 \pm 0.04^{\mathrm{cA}}$ & $6.82 \pm 0.13^{\mathrm{cA}}$ & $6.55 \pm 0.07^{\mathrm{cB}}$ & $6.12 \pm 0.06^{\mathrm{cC}}$ \\
\hline $\mathrm{T} 1$ & $7.30 \pm 0.04^{\mathrm{bA}}$ & $7.20 \pm 0.08^{\mathrm{bA}}$ & $7.09 \pm 0.03^{\mathrm{bA}}$ & $6.95 \pm 0.12^{\mathrm{bA}}$ & $6.62 \pm 0.02^{\mathrm{aB}}$ & $6.38 \pm 0.12^{\mathrm{bC}}$ \\
\hline $\mathrm{T} 2$ & $7.37 \pm 0.04^{\mathrm{aA}}$ & $7.27 \pm 0.02^{\mathrm{aA}}$ & $7.18 \pm 0.11^{\mathrm{aA}}$ & $7.03 \pm 0.06^{\mathrm{aA}}$ & $6.74 \pm 0.05^{\mathrm{bB}}$ & $6.51 \pm 0.15^{\mathrm{aC}}$ \\
\hline
\end{tabular}

Means with different superscripts in the same row (upper case letters) and column (lower case letters) differed significantly $(P<0.05)$.

C-Control T1-Carrot incorporated sausages T2- Radish incorporated sausages

\section{Conclusion}

Incorporation of vegetables has a great potential for improvement of nutritional value of developed products besides several health beneficial effects. Radish incorporated sausages were superior to sensorily compare to control. Based on the results it was concluded that turkey meat sausages incorporated with carrot and radish were acceptable upto $25^{\text {th }}$ day of refrigerated storage $\left(4+1^{\circ} \mathrm{C}\right)$ under vacuum packaging. Therefore, addition of carrot and radish has a great potential to be used in preparation of turkey meat sausages with good acceptability, lower microbial load and health benefits.

\section{References}

1. Otles S, Cagindi O. Fatty acid composition of turkey meat Sucuk (soudjuck), salami and sausages. Inter. Journal of Food Engineering. 2008; 4:1-6.

2. Mercier Y. Gattellier P, Viau M, Remingnon H, Renerre M. Effect of dietary fat and vitamin $\mathrm{E}$ on lipid and protein oxidation in turkey meat during storage. Meat Science. 1998; 48:301-317.

3. Trout ES, Hunt MC, Johnson DE, Clau JR, Kastner CL, Kropf DH et al. Chemical, physical, and sensory characterization of ground beef containing 5 to 30 percent fat. Journal of Food Science. 1992; 57:25-29.

4. Tarladgis BG, Watts BM, Younthan MT, Dungan LR. A distillation method for the quantitative determination of melanaldehyde in rancid foods. Journal of American Oilseeds and Chemical Sciences. 1960; 37:403-406.

5. Strange ED, Benedict RC, Smith JL, Swift CE. Evaluation of rapid tests for monitoring alterations in meat quality during storage. Journal of Food Protection. 1977; 40(12):843-847.

6. Chesnut CM, Ernswiler BS, Kotula AW, Young EP. Bacteriological quality of ingredients used in ground beef manufacture. Journal of Animal Science. 1977; 44:213217.
7. Keeton. Effects of fat and $\mathrm{NaCl}$ or phosphate levels on the chemical and sensory properties of pork patties. Journal of Food Science, 1983; 48:878-881.

8. Incze K. Raw fermented and dried meat products. Fleischwirtschaft. 1992; 72:58-62.

9. Santos EM, Diez AM, Fernandez CG, Rovira IJJ. Microbiological and sensory changes in Morcilla Burgos preserved in air, vacuum and modified atmosphere packaging. Meat Science. 2005; 71:249-255.

10. Ahamed ME, Anjaneyulu ASR, Sathu T, Thomas R, Kondaiah N. Effect of different binders on the quality of enrobed buffalo meat cutlets and their shelf life at refrigeration storage $\left(4 \pm 1^{\circ} \mathrm{C}\right)$. Meat Science. $2017 ; 75$ : 451-459.

11. Biswas S, Chakraborty A, Patra G, Dhargupta A. Quality and acceptability of duck patties stored at ambient and refrigeration temperature. International Journal of Livestock Production. 2011; 1(1):1-6.

12. Bhosale SS. Development and quality evaluation of chicken nuggets prepared with carrot and sweet potato. M.V.Sc. thesis submitted to GADVASU, Ludhiana, 2009.

13. Yadav S, Ashok K, Pathera, Rayees Ul Islam, Ashok K Malik, Diwakar P. Sharma. Effect of wheat bran and dried carrot pomace addition on quality characteristics of chicken sausage. Asian Australasian Journal of Animal Sciences. 2018; 31:1-9.

14. Sugita K, Yamauchi K, Chasi T, Suiko M, Miuura M. Utilization of dried radish chip extract (DRCE) in processing of sausages: An ingredient of nitrite free occurring system. Journal of Japanese Society of Food Science and Technology. 1993; 40(5):339-340.

15. Bhaskar Reddy GV, Sen AR, Pramod N. Nair, Sudhakar Reddy K, Kondal Reddy K and Kondaiah N. Effects of grape seed extract on the oxidative and microbial stability of restructured mutton slices. Meat Science. 2013; 95:288-294.

16. Bhaskar Reddy GV, Naga Mallika E, Obula Reddy B, Veena D, Suresh Naik A. Effect of foxtail millet flour on quality and storage stability of functional chevon 
sausages. The Indian Journal of Small Ruminants. 2017; 23(1):61-67.

17. Yadav S, Sharma DP. Shelf life of lowfat chevon rolls developed using whey protein concentrate, gaur gum and starch as fat replacers. Journal of Meat Science. 2004; 2(1):10-13.

18. Biswas AK, Keshri RC, Bisht GS. Effect of enrobing and antioxidants on quality characteristics of precooked pork patties under chilled and frozen storage conditions. Meat Science. 2004; 66:733-741.

19. Chenman B, Baker J, Morki AAK. Effect of packaging films on storage stability of intermediate deepfried mackerel. International Journal of Food Science Technology. 1995; 30:175-181. 